\title{
Social Demographic Analysis with the Growth and Development of Children in the Era of the COVID-19 Pandemic in Indonesia
}

\author{
Enny Fitriahadi ${ }^{1 *}$ (D), Yesi Priskila ${ }^{2}$, Endang Koni Suryaningsih ${ }^{1}$, Yekti Satriyandari ${ }^{1}$ D, Wiwit Desi Intarti ${ }^{3}$ (D) \\ ${ }^{1}$ Department of Midwifery, Faculty of Health Science, Aisyiyah University Yogyakarta, Yogyakarta, Indonesia; ${ }^{2}$ Sigi District \\ Health Office, Sulawesi, Indonesia; ${ }^{3}$ Department of Midwifery, Stikes Graha Mandiri Cilacap, Cilacap, Indonesia
}

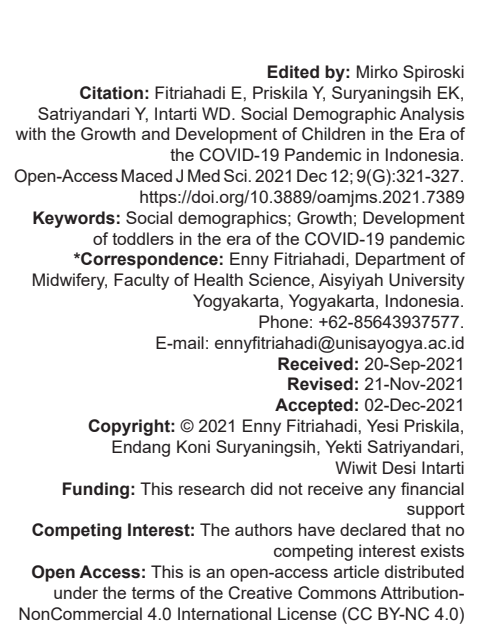

\section{Abstract}

BACKGROUND: The golden period is a phase of $0-2$ years. The parents must get a thorough stimulation of health nutrition, parenting, and education. During a pandemic like now, the growth and development of toddlers must stil be considered, especially by parents.

AIM: Exploring the sociodemographic analysis in term of growth and development of toddler during Covid-19 pandemic.

METHODS: Pregnant women and their parents visited at a primary health center in Yogyakarta, Indonesia, with inclusion criteria: (1) Toddlers aged 18-40 months, (2) mothers of all age ranges, (3) not having current disease complications, (4) mothers at all levels of education, and (5) parents at all income types. The sampling technique is total sampling using a questionnaire instrument and the KPSP format. Data processing using Chi-square statistical test.

RESULTS: The results of the bivariate analysis found that sociodemographics related to the growth and development of children under 5 were maternal education with $p=0.001$ and family income with $p=0.000$. The unrelated is the age of the toddler $p=0.156$, the mother's age with $p=0.888$, and the mother's occupation with $p=0.113$.

CONCLUSION: This study provides essential information as a new approach to improving and determining toddlers' growth and development during the COVID-19 pandemic.

\section{Introduction}

During child age, the brain experiences very rapid growth, known as the golden age. In this golden age period, most parents take advantage to optimize their children to be wise, while others do not take any advantage of the moment. Some parents assume that if childhood is a natural process and does not necessarily take any intervention, they feel that child growth is a natural process that will occur by itself without or with the intervention of his parents or anyone else [1].

Since the pandemic hits Indonesia on March 2, 2020, the incidents of COVID-19 sufferers recorded about 12,776 cases and 930 deaths widespread across the provinces. However, from those cases, only $2 \%$ are reported [2]. Various efforts to control the pandemic have significantly impacted the economic sector, daily activities, and all aspects of children's lives. These effects can be lifelong in some children. In Indonesia, there are 80 million children (approximately $30 \%$ of the total population). Compared with other groups such as older people who may have comorbid, children have the lower risk potential for complicated COVID-19 infection impact. The inequality that has occurred so far could worsen, especially about gender, income level, and disability [3], [4].

Guidelines globally recommend that children aged 1-5 years do at least $180 \mathrm{~min}$ of physical activity [5], [6]. Therefore, parents could follow these guidelines to optimize their children's growth and development [5]. However, restricting children's movements during the COVID-19 pandemic will impact their motor growth and development [7]. Therefore, the Executive Director of UNICEF has called on the government to realize that "children are the invisible victims" given the short- and long-term impacts on children's health, well-being, development, and future [8]. For this reason, the relationship between COVID-19 factors and behavior in children is essential for parents in educating children during a pandemic [9].

The Indonesian Pediatric Society in 2011 stated that the incidence of growth and development disorders in the world, in children aged $0-5$ years, reached 3 million children. The prevalence is estimated that every year about $5-10 \%$ of children born experience developmental 
delays in general [10]. The birth rate in Indonesia in 2016 reached $2,326,000$ people, amounting to $0.93 \%$ of the total population [11]. Indonesia's 2015-2019 strategic development plan states that $11.5 \%$ of children under 5 in Indonesia have growth and development disorders [12].

According to a study, some children's growth and development problems include failures to thrive, eating disorders, and sleep disorders. Other problems also include functional enuresis, functional encopresis, stuttering, and effective mutism [13]. In addition, environmental factors determine the innate potential achievement, which consists of the bio-psycho-social environment [14]. Other factors that influence child growth and development are the child's age, mother's education, family income, number of children, mother's workload, psychosocial parenting, parental personality, customs, religion, urbanization, political life, and stimulation provided by parents [15].

The government applied program aims to monitor child growth and development for children from 3 months age to 72 months age. The health-care provider, particularly midwives, who have that authority, could implement the government's program to monitor children's growth and development. Midwives could also refer children based on the indications [16]. Anthropometric measurements can describe a child's growth. Each question on the KPSP describes one aspect of development, namely, gross motor development, fine motor skills, speech, language, socialization, and independence. The questionnaire is easy, fast, and the primary health facilities could apply and determine whether children's growth and development are average or deviations [17].

Based on this background, the delay in the growth and development of toddlers is one of them due to the lack of direct involvement or stimulation of parents. The role of parents to interact with toddlers is very influential on the development of toddlers because at that time is the "Golden Age," so it is crucial for future developments for toddlers. Therefore, the researchers are interested in conducting research related to sociodemographic analysis with the growth and development of toddlers in the era of the COVID-19 pandemic at the Yogyakarta Indonesia Health Center. The purpose of this study was to find out sociodemographic analysis with the growth and development of toddlers in the era of the COVID-19 pandemic in Yogyakarta, Indonesia.

\section{Methods}

\section{Study design and partHicipants}

This cross-sectional study was conducted from April 2019 to May 2020 on 30 toddlers and their parents who visited a primary health center in Yogyakarta, Indonesia. The inclusion criteria were as follows:
(1) Toddlers aged 18-40 months, (2) mothers at all age ranges, (3) not having current disease complications, (4) mothers at all levels of education, and (5) parents at all income type. The study sample of 30 toddlers and parents was selected based on $95 \% \mathrm{Cl}$, effect size 0.05 .

\section{Data collection and analysis}

The ethics obtained from UNISA Yogyakarta Ethics Committee (No 753/KEP_UNISA/VI/2019). This study was conducted at the Public Health Center (Puskesmas) of Yogyakarta due to culture and sociodemographic background variation. In addition, at public health centers, midwives have full authority to provide service for monitoring and screening children using particular tools. In this study, the researchers used KPSP (Pre-screening Development Questionnaire). The researcher approaches potential participants and provides information about the study to the parents. The information includes the objectives of the study and the procedures of data collection. The respondents could withdraw from the study anytime without any potential risk or compensation. Once they agreed, the respondents completed the informed consent and the questionnaire. The estimated time to fill the questionnaire is about $8-10 \mathrm{~min}$. In the current study, the researcher provides souvenirs to compensate for respondents. The researcher analyzed the data using SPSS software version 2.0 with a significance level of 0.05 .

\section{Measurement}

This study uses the KPSP instrument (Prescreening Development Questionnaire) and secondary data taken from the $\mathrm{MCH}$ handbook. There are 10 items in the KPSP examination questionnaire, including the preparation of 5 items, the examination of 3 items, and the conclusion of 2 items. Therefore, there are three assessments: One requires improvement, two are capable, and three are proficient. Then to calculate the number of yes in the KPSP formula, the score is 9-10 is appropriate, $7-8$ is doubtful, and the score is $<6$ deviations.

\section{Demographic questionnaire}

Researchers have developed demographic data to obtain information about respondents' backgrounds, such as the age of toddler and mother, religion, ethnicity, education, employment status, and monthly income.

\section{Results}

The sociodemographic distribution of 30 respondents in the Yogyakarta Health Center Work Area, Indonesia, shows 30 respondents. 
Table 1 describes the primary toddlers aged 18-25 months (90\%), while parents' ages at 20-35 years about $93.3 \%$. Most respondents have graduated from school, have a college education, about $40 \%$, and mostly are housewives, $43.3 \%$. Regarding the family income, they mainly were earning less money than the regional minimum earn was approximately $86.7 \%$.

Table 1: Characteristics of respondents based on social demographics

\begin{tabular}{lll}
\hline Characteristics & Amount & Presents (\%) \\
\hline Toddlers age & & \\
$\quad$ 18-25 months & 27 & 90 \\
$\quad>25-40$ months & 3 & 10 \\
Mother age & 1 & \\
$\quad<20$ age & 28 & 3.3 \\
20-35 age & 1 & 93.3 \\
$\quad$ 35 age & & 3.3 \\
Mother's education & 6 & 20 \\
$\quad$ Elementary school to junior high school & 12 & 40 \\
$\quad$ Senior high school & 12 & 40 \\
$\quad$ College & 13 & 43.3 \\
Mother's job & 12 & 40 \\
$\quad$ Does not work & 5 & 16.7 \\
$\quad$ Non-civil servant & & 13.3 \\
$\quad$ Civil servant & 4 & 86.7 \\
Parents' income & 26 & 100 \\
$\quad$ Minimum wage rate & 30 & \\
$\quad$ Minimum wage rate & & \\
Total & &
\end{tabular}

According to Table 2, there was a significant relationship between the growth and development of children under 5 and the mother's education level $(p<0.000)$. At the same time, there is no significant relationship between the growth and development of children under 5 and some demographic variables such as toddlers age $(p=0.156)$, the mother's age $(p=0.888)$, and the mother's occupation $(p=0.113)$.

Table 2: Distribution of sociodemographic frequency with toddler growth and development $(n=30)$

\begin{tabular}{|c|c|c|c|c|}
\hline & \multicolumn{4}{|c|}{ Toddler growth and development } \\
\hline & There is & (\%) & & $(\%)$ \\
\hline \multicolumn{5}{|l|}{ Toddler age } \\
\hline $18-25$ months & 2 & 6.7 & 25 & 83.3 \\
\hline$>25-40$ months & 1 & 3.3 & 2 & 6.7 \\
\hline p-value & 0.156 & & & \\
\hline \multicolumn{5}{|l|}{ Mother's age } \\
\hline$<20$ age & 0 & 0 & 1 & 3.3 \\
\hline $20-35$ age & 3 & 10 & 25 & 83.3 \\
\hline$>45$ age & 0 & 0 & 1 & 3.3 \\
\hline p-value & 0.888 & & & \\
\hline \multicolumn{5}{|l|}{ Mother's education } \\
\hline Elementary school to junior high school & 3 & 10 & 3 & 10 \\
\hline Senior high school & 0 & 0 & 12 & 40 \\
\hline College & 0 & 0 & 12 & 40 \\
\hline p-value & 0.001 & & & \\
\hline \multicolumn{5}{|l|}{ Mother's job } \\
\hline Does not work & 3 & 10 & 10 & 33.3 \\
\hline Non-civil servant & 0 & 0 & 12 & 40 \\
\hline Civil servant & 0 & 0 & 5 & 16.7 \\
\hline$p$-value & 0.113 & & & \\
\hline \multicolumn{5}{|l|}{ Parents' income } \\
\hline Minimum wage rate & 3 & 10 & 1 & 3.3 \\
\hline$<$ Minimum wage rate & 0 & 0 & 26 & 86.7 \\
\hline p-value & 0.000 & & & \\
\hline
\end{tabular}

\section{Discussion}

\section{Social demographics of respondents}

Toddler age

The golden toddler age is a crucial period in child growth and development due to one moment happening. During this period, the brain will develop massively, and the toddler imitates his environment that impacts his future cognitive and social development [1].

During this golden age too, caregivers, particularly parents, need to know the growth and development of their children. Therefore, parents will be aware of the abnormalities of their children and will seek help from the health care provider, particularly midwives, to screen as the early detection if needed. Ultimately, this screening will prevent permanent developmental disorders during this golden age period [18].

\section{Mother's age}

The results showed that most respondents were aged 20-35 years, as many as 28 respondents (93.3\%). This study, in line with the previous research, conducted by Kurniawati and Hanifah (2014). They highlighted that the most of the mother's age group was $24-40$, about $76.6 \%$ of all respondents. The age of the mother showed that at that age showed a mature and mature age. Age of maturity level will be more in thinking and working [19]. The role of caregivers and family characteristics (gender and age of caregivers, number of persons, and children per household) was also associated with child growth and development [20].

\section{Mother's education}

The results showed that most respondents had high school education as many as 12 respondents (40\%) and PT education as many as 12 respondents (40\%). Research conducted by Herentina (2014) showed that most of the respondents had high school education as many as 11 mothers of children under $5(43.3 \%)$. Someone with higher education will be more rational in dealing with life's problems, using effective coping than parents with low education [21]. Education is a process of changing the attitudes and behavior of a person or group of people to mature humans through teaching or training efforts [22].

Education affects a mother's knowledge in child care [22]. However, this study shows that the growth and development of children under 5 are not affected by the mother's characteristics, especially education. This phenomenon is because the growth and development of toddlers are more influenced by stimulation, that stimulation activities affect the growth and development of toddlers. The stimulation itself can be done by the mother and does not depend on education [22]. However, education affects the level of stimulation for child development [23].

\section{Mother's job}

The results showed that most respondents did not work or as housewives 13 respondents (43.3\%). 
Most of the work done by parents is to meet economic needs and as an additional source of family income. By the theory that economic needs often require both parents to be forced to work and leave their children to meet all the needs of the family, so that there is less care and interaction with children. A person's job will earn income so that person will use health facilities to check health because the person feels that he has enough money to come to health facilities [21].

During this pandemic, the sudden loss of household income causes instability in the family's economic situation, leading to poverty. Consequently, the income and consumption of poor and vulnerable families who have family members with children will be reduced due to inadequate savings. Recent research by the United Nations University-World Institute for Development Economics Research states that the economic downturn caused by the pandemic could increase the world's poverty level to half a billion people or $8 \%$ of the world's population [24]. Furthermore, Bappenas projections show that the probability of Indonesia's population falling into poverty rises to $55 \%$, with around $27 \%$ of middle-class candidates estimated to experience worrying income insecurity [25].

The results of this study indicate a relationship between a mother's work and the growth and development of toddlers. This result can happen because many factors influence the growth and development of toddlers. In this study, work affects the growth and development of toddlers.

\section{Parents' income}

The results showed that most of the respondents' income was less than the minimum wage of 26 respondents (86.7\%). Therefore, mothers whose income is less than minimum regional earnings (UMR) mostly have children under 5 with average growth and development and mothers who have income according to the minimum wage. This resulting study proves that regardless of the income earned by the mother, the growth and development of toddlers are primarily in the normal category, so it can be said that income affects the growth and development of toddlers. In contrast, Monks (2012) found that good work or family income will support the growth and development of children because parents can provide both primary and secondary children's needs. Thus, the psychosocial development of children can develop properly if all the needs of children are met [26].

On the other hand, a longitudinal study of 900 European-American children from the National Institute of Child Health and Human Development showed that mothers who worked $30 \mathrm{~h}$ or more per week had reduced quality of care for their children. Astudy from the National Longitudinal Survey of Youth invited 6144 children who have full-time and part-time worker mothers. Compared with children whose part-time worker mothers during the $1^{\text {st }}$ year after birth, children whose full-time workers mothers show negative results on children's cognitive and behavior at the age of 3-8 years [27]. A low family income and a crowded house will impact the growth and development of children [23].

Although Indonesia has made significant progress in reducing extreme poverty, only 52 million Indonesians can be considered to have a secure income. In 2019 , around $10 \%$ of Indonesia's population lived in extreme poverty; this increased to $13 \%$ for children and adolescents [8]. However, these percentages cover a considerable gap and the various forms of poverty that affects children in Indonesia beyond household income. Nine out of 10 children experience a deficiency in at least one aspect of child welfare, such as access to food and nutrition, health, education, housing, water and sanitation, and child protection. In addition, more than half of the child population in Indonesia suffers from at least two non-financial deprivations. Based on research, families with less growth and development are better than families who can afford it [28], [29].

\section{Toddler growth and development}

Stimulation of brain tissue is critical during the golden period of toddlers. The more stimulation the mother gives to the toddler, the brain tissue will develop up to $80 \%$ by 3 years. On the other hand, if toddlers are never given enough stimulation, their brain tissue will shrink so that brain function will decline. Lack of stimulation in toddlers can affect the development of brain intelligence, developmental deviations, and even permanent developmental disorders. Internal and external factors influence growth and development. Internal factors include gender, racial differences, age, genetics, and chromosomes.

In comparison, external factors include the social environment, economy, nutrition, and psychological stimulation. The golden period for toddlers takes place in the age range of $0-5$ years. This age is the initial phase of toddler growth and will affect the next phase [30]. A study in Italy showed that children aged under 3-6 years experienced a decline in child development during the COVID-19 pandemic [31].

During the pandemic, Indonesia was previously an example of a country with "three burdens of malnutrition" long before the COVID-19 Pandemic. First, Indonesia has 7 million children who are stunted. This condition makes Indonesia the fifth country in the world with the most stunting toddlers. Second, more than 2 million children are underweight (weight disproportionate to height), and another 2 million are overweight or obese. Third, almost half of the pregnant women experience anemia because the food consumed does not contain enough vitamins and minerals (micronutrients) needed [17]. Poor health status increases the risk of infection, including COVID-19, and worsens the prognosis for recovery. 
For this reason, an understanding of the increased risk of exposure experienced, especially in malnourished children, needs to be improved. Meeting the needs of children during the COVID-19 pandemic will encourage children's behavior to be active [32].

Indonesia faces complex challenges due to the three burdens likely to worsen due to the COVID-19 pandemic. First, children can be malnourished for various reasons (direct causes, existing ones, and basic ones). The three most common direct causes of malnutrition are inadequate breastfeeding practices and poor diet, suboptimal parenting practices, inadequate nutrition and care for pregnant women and women, the high number of infectious diseases mainly due to an unclean living environment, and inadequate access to inadequate health services.

These factors are exacerbated by widespread poverty, unemployment, low education levels, and unpleasant psychological experiences [8], [33]. Therefore, recent studies conducted during the COVID-19 pandemic in children and adolescents need to focus on their growth and development [34], [35].

\section{Care for early childhood development}

According to $\mathrm{WHO}$, counseling and services should be prioritize for responsive parenting, feeding, and protecting children from abuse and violence (WHO, 2020) [36]. In the period of the spread of COVID-19, health-care providers related to the target of toddlers have roles, including coordinating cross-programs at the Puskesmas/health facilities to determine steps to deal with the COVID-19 pandemic. Health-care providers also need to conduct integrated socialization with other programs, including people who have children under 5 , on preventing the spread of COVID19 , emergency conditions, and information on the nearest referral hospital, analyzing data on under-5 at risk that requires follow-up. In addition, health-care providers also need to coordinate cadres, RT/RW/ village heads, and community leaders regarding child targets and services routine health in the COVID-19 pandemic. Providing health services to toddlers by conducting triage, applying the principles of Infection Prevention and Control (PPI), and physical distancing in the health services provided [37].

Provision of a safe space for physical activity is critical while maintaining distance, such as the availability and accessibility of playgrounds that can be adapted and implemented during the COVID-19 pandemic [38], [39]. In Colombia, a closed playground has been implemented during the pandemic to optimize child development [40]. This closed play program implements social distancing at an affordable cost [41], [42]. Previous research has shown that children are at higher risk during a pandemic and require specific interventions to minimize the impact of developmental delays [43]. Therefore, the role of parents in providing stimulation and interacting with infants will affect the success and optimal growth and development of toddlers [44]. For this reason, parents must consider the impact on children's health both physically and mentally [45].

\section{Conclusion}

Social demographics related to the growth and development of children under 5 are maternal education and family income. Therefore, this study provides essential information as a new approach to improving and determining toddlers' growth and development during the COVID-19 pandemic.

\section{References}

1. Kemenpppa, Child Development Phase; 2016. Available from: https://www.kemenpppa.go.id/index.php/page/read/31/586/ fase-tumbuh-kembang-anak. [Last accessed on 2020 Jun 18].

2. Channel News Asia. Indonesia's Health System on the Brink as Coronavirus Looms; 2020. Available from: https://www.channelnewsasia.com/news/asia/ Covid19-indonesia-health-system-brink-coronavirus-12574256

3. Guan H, Okely AD, Aguilar-Farias N, Del Pozo Cruz B, Draper CE, El Hamdouchi A, et al. Promoting healthy movement behaviors among children during the COVID-19 pandemic. Lancet Child Adolesc Health. 2020;4(6):416-8. https://doi. org/10.1016/S2352-4642(20)30131-0 PMid:32458805

4. Bates LC, Zieff G, Stanford K, Moore JB, Kerr ZY, Hanson ED, et al. COVID-19 impact on behaviors across the 24-hour day in children and adolescents: Physical activity, sedentary behavior, and sleep. Children. 2020;7(9):138. https://doi.org/10.3390/ children7090138

PMid:32947805

5. World Health Organization. Guidelines on Physical Activity, Sedentary Behaviour, and Sleep for Children under 5 Years of Age. Geneva, Switzerland: World Health Organization; 2019.

6. Okay AD, Ghersi D, Hesketh KD, Santos R, Loughran SP, Cliff DP, et al. A collaborative approach to adopting/adapting guidelinesthe Australian 24-hour movement guidelines for the early years (birth to 5 years): An integration of physical activity, sedentary behavior, and sleep. BMC Public Health. 2017;17Suppl 5:869. https://doi.org/10.1186/s12889-017-4867-6

PMid:29219094

7. Crawley E, Loades M, Feder G, Logan S, Redwood S, Macleod J. Wider collateral damage to children in the UK because of the social distancing measures designed to reduce the impact of COVID-19 in adults. BMJ Paediatr Open. 2020;4(1):e000701. https://doi.org/10.1136/bmjpo-2020-000701

PMid:32420459

8. UNICEF. Children in Indonesia: A Multidimensional Analysis of Poverty, Mobility, and Disadvantage. Jakarta: UNICEF; 2020.

9. Aguilar-Farias N, Toledo-Vargas M, Miranda-Marquez S, Cortinez-O'Ryan A, Cristi-Montero C, Rodriguez-Rodriguez F, 
et al. Sociodemographic predictors of changes in physical activity, screen time, and sleep among toddlers and preschoolers in chile during the COVID-19 pandemic. Int J Environ Res Public Health. 2020;18(1):176. https://doi.org/10.3390/ijerph18010176 PMid:33383721

10. IDAl. Recognizing Common Developmental Delays in Children; 2013. Available from:http://www.idai.or.id/public-articles/ seputar-kesehatan-anak. [Last accessed on 2020 Jun 18].

11. BPS. Projection of Indonesian Occupation 2010-2035. Jakarta: Kementerian PPN/BAPPENAS, BPS, UNPF; 2016.

12. Kemenkes Republik Indonesia. The Strategic Plan of the Ministry of Health for 2015-2019. Decree of the Minister of Health of the Republic of Indonesia Number HK.02.02/MENKES/52/2015; 2019.

13. Adıbelli $D$, Sümen A. The effect of the Coronavirus (COVID-19) pandemic on health-related quality of life in children. Child Youth Serv Rev. 2020;119:105595. https://doi.org/10.1016/j. childyouth.2020.105595

PMid:33071408

14. Asiyah S, Harjito K, Suwoyo. The effectiveness of one hour stimulation method with mothers on the development of children aged 12-24 months. Health Forikes Voice Res J. 2010;1:105-14.

15. Ariani A, Yosoprawoto M. Child age and mother's education as risk factors for child development disorders. Brawijaya Med J . 2012;27:118-21. https://doi.org/10.21776/ ub.jkb.2012.027.02.13

16. Ramli, Agho KE, Inder KJ, Bowe SJ, Jacobs J, Dibley MJ. Prevalence and risk factors for stunting and severe stunting among under-fives in north maluku province of Indonesia. BMC Pediatrics. 2009;9:64. DOI. 10.1186/1471-2431-9-64

17. Kementerian Kesehatan RI. Technical Instructions for Immunization Services during the COVID-19 Pandemic; 2020.

18. Santi Y. Overview of the Psychosocial Development of Children aged 3-6 Years in a Toddler Child Orphanage Tunas Bangsa Cipayung. Surakarta: Jurnal Universitas Muhammadiyah Surakarta; 2012. Available from: http://www.repository.uinjkt. ac.id/dspace/handle/123456789/25663. [Last accessed on 2020 Jun 18]

19. Kurniawati $H$. The Relationship of Mother's Knowledge about Stimulation of Toddler Growth and Development of Toddlers Age 12-36 Months at Posyandu Kasih Ibu 7 Banyu Urip Klego Boyolali. Jurnal Kebidanan. Indonesia: Akademi Kebidanan Mamba'ul 'Ulum Surakarta; 2014.

20. Ibarra-Mora J, Alvarez C, Aguilar-Farias N, Escalona PC, Cristi-Montero C, Arroyo PD, et al. Guía de Actividad Física en Familia Durante Confinamiento; Mesa Técnica Interministerial Para la Educación Física, Actividad Física y Deporte Escolar en pandemia Gobierno de Chile; Gobierno de Chile: Santiago, Chile; 2020.

21. Notoatmodjo S. Health Research Methodology. Jakarta: Rineka Cipta; 2012.

22. Soetjiningsih S. Child Growth. Jakarta: EGC; 2014.

23. Instituto Nacional de Estadísticas-Chile. Censo de Población y Vivienda 2017;2017.Available from: https://www.redatam-ine.ine. cl/redbin/rpwebengine.exe/portal?base=censo_2017\&lang=esp [Last accessed on 2020 Sep 30].

24. Sumner A, Hoy C, Ortiz-Juarez E. Estimating the Impact of COVID-19 on Global Poverty Rates WIDER Working Paper No. 2020/43. Helsinki: UNU-WIDER; 2020.

25. Black R E. Kekurangan gizi pada ibu dan anak: Nutrition deficiency to mother and child: Global and regional exposure and its impact on the health. 2008;371:9608. https://doi. org/10.52436/1.jpmi.7

26. Monks FJ. Developmental Psychology. $16^{\text {th }}$ ed. Yogyakarta: Gadjah Mada University Press; 2012.

27. Deviani M. Children of Working Parents, Artikel Elektronik;
2016. Available from: http://www.mutiara-deviani.blogspot co.id/2016/06 [Last accessed on 2020 Jun 03].

28. Aguilar-Farias N, Miranda-Marquez $S$, Martino-Fuentealba $P$, Sadarangani KP, Chandia-Poblete D, Mella-Garcia C, et al. Chilean physical activity report card for children and adolescents: Full report and international comparisons. J Phys Act Health. 2020;17:807-15. https://doi.org/10.1123/jpah.2018-0553

29. Aguilar-Farias N, Cortinez-O'Ryan A, Sadarangani KP, von Oetinger A, Leppe J, Valladares M, et al. Results from Chile's 2016 Report card on physical activity for children and youth. J Phys Act Health. 2016;13 Suppl 11:S117-23. https://doi. org/10.1123/jpah.2016-0314

PMid:27848748

30. Doyle, Daniel A.D. Physical Growth Of Infants And Children. CDC. Track Your Child's Developmental Milestones; 2012.

31. Dellagiulia A, Lionetti $F$, Fasolo $M$, Verderame $C$, Sperati $A$ Alessandri G. Early impact of COVID-19 lockdown on children's sleep: A 4-week longitudinal study. J Clin Sleep Med. 2020;16(9):1639-40. https://doi.org/10.5664/jcsm.8648 PMid:32620188

32. Elige Vivir Sano Ministerio de Desarrollo Social y Familia Gobierno de Chile. Vida Saludable en Casa; 2020. Available from: http://www.eligevivirsano.gob.cl/vida-saludable-en-casa [Last accessed on 2020 Sep 30].

33. Lee H, Kim Y, Terry J. Adverse childhood experiences (ACEs) on mental disorders in young adulthood: Latent classes and community violence exposure. Prev Med. 2020;134:106039. https://doi.org/10.1016/j.ypmed.2020.106039 PMid:32097756

34. Zenic N, Taiar R, Gaelic B, Blazevic M, Maric D, Pojskic H, et al. Levels and changes of physical activity in adolescents during the COVID-19 pandemic: Contextualizing urban vs. rural living environment. Appl Sci. 2020;10(11):3997. https://doi. org/10.3390/app10113997

35. Mitra R, Moore SA, Gillespie M, Faulkner G, Vanderloo LM, Chulak-Buzzer T, et al. Healthy movement behaviors in children and youth during the COVID-19 pandemic: Exploring the role of the neighborhood environment. Health Place. 2020;65:102418. https://doi.org/10.1016/j.healthplace.2020.102418 PMid:32871499

36. World Health Organization. Helping Children Cope with Stress during the 2019-nCoV Outbreak. Geneva: World Health Organization; 2020.

37. Gugus Tugas Percepatan Penanganan COVID-19. Guidelines for Rapid Medical and Public Health Handling of COVID-19 in Indonesia; 2020.

38. Triana CA, Sarmiento OL, Bravo-Balado A, Gonzalez SA, Bolivar MA, Lemoine $P$, et al. Active streets for children: The case of the bogota ciclovia. PLoS One. 2019;14(5):e0207791. https://doi.org/10.1371/journal.pone.0207791 PMid:31091227

39. Torres A, Sarmiento OL, Stauber C, Zarama R. The ciclovia, and cicloruta programs: Promising interventions to promote physical activity and social capital in Bogota, Colombia. Am J Public Health. 2013;103(2):e23-30. https://doi.org/10.2105/ ajph.2012.301142

PMid:23237179

40. O'Donovan G, Ardila KF, Ramirez HH, Ramirez HM, Gomez NR, Sarmiento OL. Community Physical Activity Interventions during the COVID-19 Pandemic: Where there's a Will, there's a Way! 2020. Available from: https://www.blogs.bmj.com/ bjsm/2020/08/03/community-physical-activity-interventionsduring-the-covid-19-pandemicwhere-theres-a-will-theres-away. [Last accessed on 2020 Jun 18] https://doi.org/10.3390/ ijerph18010176

41. C40 Cities Climate Leadership Group. Prioritising Cyclists and 
Pedestrians for a Safer, Stronger Recovery; 2020. Available from: https://www.c40knowledgehub.org/s/article/prioritising-cyclistsand-pedestrians-for-a-safer-stronger-recovery?language $=$ en us. [Last accessed on 2020 Jun 18].

42. The New York Times. 'Corona Cycleways' Become the New Post-Confinement Commute; 2020. Available from: https://www. nytimes.com/2020/06/12/business/paris-bicycles-commutecoronavirus.html. [Last accessed on 2020 Jun 18].

43. Aishworiya R, Kang YQ. Including children with developmental disabilities in the equation during this COVID-19 pandemic. J Autism Dev Disord. 2021;51(6):2155-8. https://doi. org/10.1007/s10803-020-04670-6
PMid:32816170

44. Dudek H, Myszkowska-Ryciak J. The prevalence and sociodemographic correlates of food insecurity in Poland. Int $\mathrm{J}$ Environ Res Public Health. 2020;17(17):6221. https://doi. org/10.3390/ijerph17176221

PMid:32867149

45. Wagner K. New Findings About Children's Mental Health During COVID-19; 2020. Available from: https://www.psychiatrictimes. com/view/new-findings-children-mental-health-covid-19. [Last accessed on 2020 Jun 18]. https://doi.org/10.1016/j. psychres.2020.113429 